\title{
Role of Integrating Business Intelligence Systems and Knowledge Management in Supporting Decision-Making Process in Saudi Electricity Company
}

\author{
Fudhah A.AlSelami ${ }^{1}$, Ibrahiem M.ELEmary ${ }^{2}$, and Huda M.Alamoudi ${ }^{3}$ \\ ${ }^{I}$ Management Information system, University of Jeddah-Alkamel Branch, UJ, Jeddah,Saudi Arabia. \\ ${ }^{2}$ Information Science Department, King Abdul Aziz University, KAAU, Jeddah, Saudi Arabia. \\ ${ }^{3}$ Information Science Department, King Abdul Aziz University, KAAU, Jeddah, Saudi Arabia.
}

ORCID: 0000-0001-6953-9600 (Fudhah)

\begin{abstract}
Information is the lifeline of any organization as it plays a very important role in the decision making process. Therefore, the efficiency of the organization management has become dependent on that information and its good use. The more fast and accurate information is, the more effective and efficient decisions taken and vice versa, therefore, this study focused on examination and analysis of how to achieve the information integration process through data accessibility, accuracy, completeness and security under the umbrella of integrating business intelligence and knowledge management in order to improve decision-making in organizations in an effective way, and the researchers was keen to provide insight on how companies go through the process of information integration, the Saudi Electricity Company in particular, and explore methods of integrating business intelligence and knowledge management systems to improve the process of information integration, how to enrich data by strengthening source data in the data warehouse with knowledge sharing process practices, and how to improve the process of information integration and use it in supporting better decision-making processes, and identifying the main challenges faced by organizations to implement this process. The researchers applied the qualitative exploratory experimental approach using three questionnaires directed to the study sample, that is (331) employees of business intelligence system specialists or consultants, business intelligence system users, and decision makers; and the responses of the sample members were analyzed using SPSS. The study concluded that the responses of the sample members about the application of information integration process is very high; and that data consolidation and enrichment is established by intellectual capital through the application of knowledge exchange practices, information transfer, providing open door policy to correct data, enrich data warehouse and acquire new insights and knowledge for making better decisions based on verbal communication and semi documented forms of communication.
\end{abstract}

The researchers reviewed the process of integrating business intelligence and knowledge management systems to prepare, plan and implement the system, processes and results of information integration and the challenges they faced during implementation, and reached to the relational framework model that focuses on how the information integration process resulting from the integration of business intelligence and knowledge management systems occurs, and includes stage of knowledge integration "that reflects organizing, documenting and raising new knowledge expressed in the form of lessons learned about the process of integrating information and consolidating business intelligence data from a knowledge management perspective, by documenting practices of integrating knowledge in the institutional knowledge warehouse for better decision-making.

Keywords: Information Integration; BI; KM; Knowledge Sharing; Data Quality; Data Enrichment; Information Transfer; Data Governance; Data and Text Mining and OLAP.

\section{INTRODUCTION}

The main problem that modern business organizations face is not lack of data, on the contrary - it is the huge amount of data that requires increasing time to organize, categorize and transform into useful information. Therefore, there is an urgent need to transform the huge amounts of data into useful information right on time to provide managers with a solid base that contributes to their decision-making. Although BI systems are related to explicit knowledge only, whereas KM is related to implicit and explicit knowledge, it can be said that both concepts aim to transform data and information into knowledge.

Given that $\mathrm{KM}$ is mainly concerned with the internal environment of the organization and $\mathrm{BI}$ is mainly concerned with its external environment, the integration of both systems in one system can achieve some kind of balance between implicit knowledge which provides sustainable competitive advantage (because competencies are difficult to imitate), and explicit and coded knowledge which is easy to transform and is also available for all stakeholders. As for the organization, KM system is a system that can contribute to defining this balance for every organization, and BI plays an important role in this system through its ability to accelerate knowledge production and transfer process, while KM helps collect and organize group knowledge and make it available on the basis of sharing [1]

Data usually require more enrichment through human knowledge to transform it into useful information, which can 
provide a solid foundation for higher management to make strategic decisions; this process is known as information integration, which is a process of applying programs, techniques and practices that support information integration from diverse sources with different conceptual, contextual and typographical representations. Information integration allows integration of data from unorganized and semi-organized sources through techniques such as data mining, text mining and multimedia content processing; it allows collection, integration and organization of the organization's data and information from a large group of heterogeneous data sources in one destination to monitor data where it is displayed in a standardized format, which helps users access correct information faster and determine meaningful strategic insights that depends on four main elements: basic information accessibility, accuracy, completeness and security.

When the above four elements are ensured, information can be regarded consistent and reliable enough (i.e. information integrity has been established) to undergo enrichment with human knowledge and be a foundation for optimal decisionmaking. According to theoretical approached, given the individuals who use information and share it, and make decisions in any organization, any process of integration between functional departments and KM must include the transformation and use of knowledge concentrated in human resources level.

\section{PREVIOUS RELATED WORKS}

In [2-6], the authors suggest theoretical approaches to integrate $\mathrm{BI}$ and $\mathrm{KM}$; and to ensure information integrity, so what must be verified is: first, whether error detection and/or generation of new insights occurs during the use BI information, this step can result from BI user in a company or BI/ information technology specialist responsible for maintaining the accuracy of BI systems data. Second, information is shared with colleagues to communicate an error or a new insight resulting from BI system information. Third, in case there is specific errors in basic data, information is transferred to discover the causes of the detected errors and correct them, and in necessary, load new data files that provide reliable and accurate to be integrated in BI tools. This process can be performed manually or files can be imported through Electronic Data Interchange (EDI) or by updating source databases. In case of new insights resulting from BI systems' information, knowledge is communicated all over the organization to enrich other potential databases or integrate the results in the industrial knowledge of the company and current practices and store them a knowledge warehouse or center.

Lastly, once information is transferred, it can be said that information integration is achieved and the organization can go back to using newly enriched information to achieve its operational and strategic objectives. For organizations that succeed in integration of BI and KM systems, the strategic orientation of $\mathrm{KM}$ is necessary, and organizational creativity has strong impact on organizational performance in modern businesses [7], where organizations that undertake to integrate $\mathrm{BI}$ and $\mathrm{KM}$ systems, tend to be in the midst of fast internal or industrial changes, such as the appearance of large amounts of data, the strong push of the industry towards creativity, information revolution, or environmental challenges [6]. Fast growing technological capabilities for data collection and generation, require the use of software solutions and tools that can transform processed data into valuable information and knowledge.

Shahzad \& Khan [8] indicate that BI and KM integration helps organizations "through using correct information in the right time". The main objective of information integration is to ensure the organization's ability to respond quickly to market changes. Therefore, Chang et al [9] indicate that information from internal and external sources, as well as market information and knowledge, should be collected, integrated and regularly updated to be used by all organization levels to respond to different market situations. On the other hand, Shahzad \& Khan [8] argue that to ensure the successful integration of BI and KM systems, organizations need to rely on several critical success factors, which include committed managerial support, sponsorship of the integration process, and a clear business vision and a firm status to defend the need for $\mathrm{KM}$ and $\mathrm{BI}$ integration. The approach based on business and project management allows determination of the proper project range, planning, and adoption of continuous improvement and data quality/management framework. This leads to increase in productivity and efficiency of operations, and the ability to predict organizational challenges and plan the optimal strategies about how to process them.

\section{PROBLEM STATEMENT AND THE METHODOLOGY OF SOLUTION}

The main objective of this research is to study, examine and analyze how to achieve information integration through data accessibility, accuracy, completeness and security under the integration of $\mathrm{BI}$ and $\mathrm{KM}$ to improve decision-making in organizations effectively, and how to use, adjust and build upon this experiment by other organizations.

This study is the first of its kind in the Arab world, and Saudi Arabia in particular, according to the researcher's knowledge of this field, in addition to the scarcity of modern studies that theoretically address the concepts of integration between BI and $\mathrm{KM}$ systems, omitting the reality of application in organizations as there are no case studies of application in organizations, the failure of these studies to reveal specific facts of how to execute this integration in organizations and investigating the challenges facing integration process in organizations, and the need for more applied studies in environments that apply and support BI and KM systems.

The researchers also highlights the importance of creating supportive environments for BI and KM systems. With this in mind, the present study aims to analyze how the integration of $\mathrm{BI}$ and KM systems in organizations can contribute to improving information integration, and thus support decisionmaking; and that data consolidation must be strongly rooted in the company's knowledge sharing and information transfer practices. While the lack of adequate documentation of the company's operations leads to repetition of previous mistakes or ineffective behavior patterns, prevents the organization from 
learning from previous operational situations in a complete manner, and slows down overall organizational learning. Therefore, it is possible to complete and expand (see Figure 1) the information integrity model (Niesel,) [6] to the relational framework model to explain how the process of the information integration system occurs between business intelligence and knowledge management, and to include a new fifth stage in the integration of knowledge that reflects the organization, documentation and upload of new knowledge expressed in the form of lessons learned about the process of information integration and the consolidation of business intelligence data by the perspective of knowledge management, and stored in the organization's knowledge hub so that the concerned stakeholders can understand, learn and repeat the processes that contributed to the process of information integration and knowledge integration, thus ensuring continuous improvement in how information transfer, knowledge sharing and optimal decision-making are performed in the best organization.

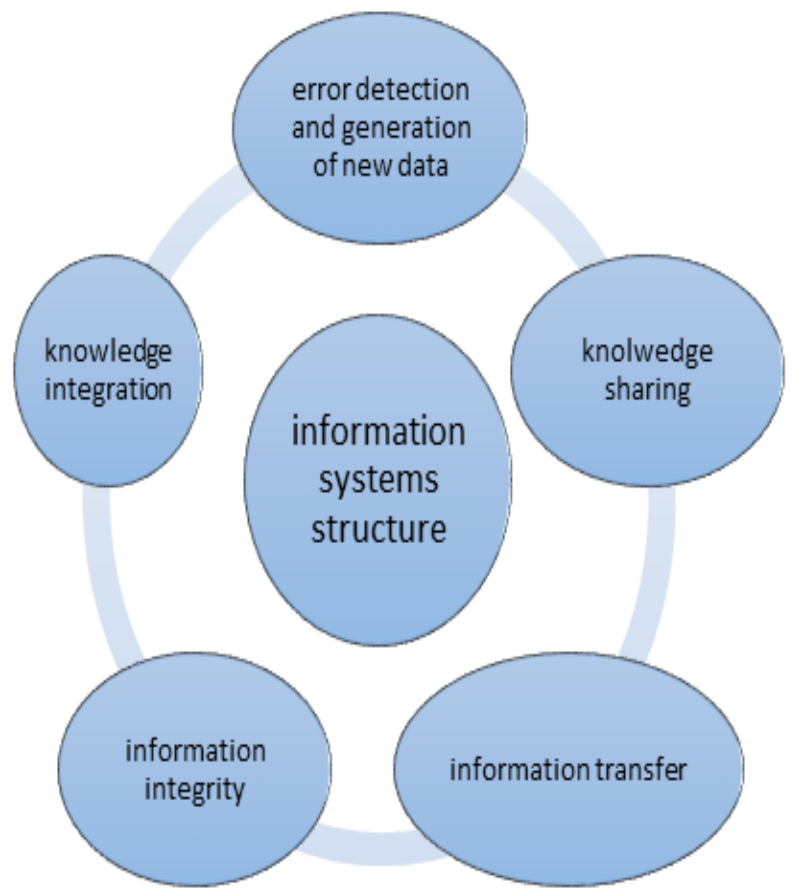

Fig1. The process of information and knowledge integration

To explore and understand the problem, the researcher applied the qualitative experimental exploratory approach in the form of a survey consisting of different questionnaire models that were directed to three main target groups: regular business intelligence users; business intelligence or information technology specialists; and decision makers who use business intelligence for important tactical or strategic considerations in paper and electronic form.

The study population consisted of (1995) employees, and a stratified sample was chosen from the study population, with a rate of $16 \%$ for both business intelligence users and decision makers, with the study sample's inclusion of all employees of business intelligence systems specialists because of their small number, as the final application sample for the study represented (331) employees, which included (224) employees of business intelligence systems users, (94) decision makers, and (13) business intelligence systems specialists in operational, tactical and strategic levels. The data were analyzed using the SPSS statistical program and the following statistical methods: frequency and percentages, the Alpha Cronbach coefficient, the Pearson correlation coefficient, the Holste equation, the mean and standard deviation, the ANOVA test, the Chevy test, and the "T" test.

\section{THE ACHIEVED NUMERICAL RESULTS AND DISCUSSION}

The study population was distributed according to the demographic variables, which are the company's functional experience, age and gender as follows:

- The most responsive to questionnaires from users of business intelligence systems are those with (more than 10 years) of experience with $43 \%$, followed by those with (from 5 to 10 years) of experience with $34 \%$, and the most responsive age group was those (over 45 years) with $49.5 \%$, followed by the age group whose ages ranged between (35 - less than 45 years) by $30.5 \%$, and the majority of them were male, with $96.4 \%$, while females were $3.6 \%$ of the total sample.

- The most responsive to questionnaires from decision makers are those with (more than 10 years) of experience with $45 \%$, followed by those with (from 5 to 10 years) of experience with $34 \%$, and the most responsive age group was those (over 45 years) with $51 \%$, followed by the age group whose ages ranged between (35 - less than 45 years) by $32 \%$, and the majority of them were male, and the male response with $100 \%$ of the total sample.

- The most responsive to questionnaires from specialists of business intelligence systems are those with (from 5 to 10 years) of experience with $46 \%$, followed by those with (more than 10 years) of experience with $31 \%$, and the most responsive age group was those (over 45 years) with $38.5 \%$, Followed by the age group whose ages ranged between (25 - less than 35 years) by $38.5 \%$, and the majority of them were male, and the majority of them were male, with $92 \%$, while females were $8 \%$ of the total sample.

And when examining the role of business intelligence systems in supporting decision-making through the collected questionnaires, responses of respondents of the sample appeared as indicated in Table (1): 
International Journal of Engineering Research and Technology. ISSN 0974-3154 Vol.13, No.4 (2020), pp. 744-755

(C) International Research Publication House. https://dx.doi.org/10.37624/IJERT/13.4.2020.744-755

Table 1. Responses of the sample members about the role of business intelligence systems in supporting decision-making

\begin{tabular}{|c|c|c|c|c|c|c|c|}
\hline \multirow[b]{2}{*}{ Questions } & \multirow[b]{2}{*}{ Answers } & \multicolumn{2}{|c|}{ Users } & \multicolumn{2}{|c|}{ Specialists } & \multicolumn{2}{|c|}{ Decision makers } \\
\hline & & $\begin{array}{ll}\overrightarrow{0} & Z \\
0 & \Xi \\
0 & \Xi \\
0 & 0 \\
0 & \oplus \\
\infty & 0 \\
\infty & 0\end{array}$ & 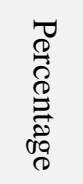 & $\begin{array}{ll}\overrightarrow{0} & Z \\
0 & \Xi \\
0 & \Xi \\
0 & 0 \\
0 & \oplus \\
0 & 0 \\
\infty & 0\end{array}$ & 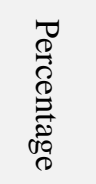 & 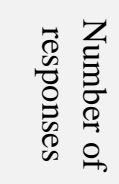 & 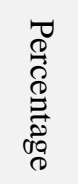 \\
\hline \multirow{5}{*}{$\begin{array}{l}\text { What type of business } \\
\text { intelligence tools do you } \\
\text { use? (multiple answers } \\
\text { allowed) }\end{array}$} & Data warehouses & 217 & $97 \%$ & 13 & $100 \%$ & 92 & $98 \%$ \\
\hline & Data Mining systems & 67 & $30 \%$ & 11 & $85 \%$ & 89 & $95 \%$ \\
\hline & Text Mining systems & 29 & $13 \%$ & 9 & $69 \%$ & 73 & $78 \%$ \\
\hline & $\begin{array}{l}\text { BI Dashboards) / work } \\
\text { environment (user interface) }\end{array}$ & 206 & $92 \%$ & 11 & $85 \%$ & 90 & $96 \%$ \\
\hline & BI reports & 215 & $96 \%$ & 12 & $93 \%$ & 89 & $95 \%$ \\
\hline \multirow{5}{*}{$\begin{array}{l}\text { For what purpose is } \\
\text { business intelligence } \\
\text { applied in your } \\
\text { organization? (multiple } \\
\text { answers allowed) }\end{array}$} & $\begin{array}{l}\text { Databases to collect and store } \\
\text { data }\end{array}$ & 201 & $90 \%$ & 10 & $77 \%$ & 0 & $0 \%$ \\
\hline & Data analysis & 190 & $85 \%$ & 11 & $85 \%$ & 91 & $97 \%$ \\
\hline & $\begin{array}{l}\text { Providing decision-making } \\
\text { processes with information } \\
\text { about the current situation }\end{array}$ & 152 & $68 \%$ & 12 & $93 \%$ & 93 & $99 \%$ \\
\hline & $\begin{array}{l}\text { Alert about potential } \\
\text { problems }\end{array}$ & 123 & $55 \%$ & 19 & $77 \%$ & 88 & $94 \%$ \\
\hline & $\begin{array}{l}\text { Guiding future planning by } \\
\text { providing the necessary } \\
\text { information }\end{array}$ & 139 & $62 \%$ & 12 & $93 \%$ & 92 & $98 \%$ \\
\hline \multirow{5}{*}{$\begin{array}{l}\text { How often do you use } \\
\text { business intelligence } \\
\text { solutions in your work? }\end{array}$} & Everyday & 157 & $70 \%$ & 12 & $93 \%$ & 71 & $75 \%$ \\
\hline & Several times a week & 67 & $30 \%$ & 3 & $23 \%$ & 10 & $11 \%$ \\
\hline & Several times a month & 0 & $0 \%$ & 2 & $15 \%$ & 8 & $9 \%$ \\
\hline & Several times a year & 0 & $0 \%$ & 1 & $7 \%$ & 5 & $5 \%$ \\
\hline & Not used & 0 & $0 \%$ & 0 & $0 \%$ & 0 & $0 \%$ \\
\hline
\end{tabular}

- When examining the role of business intelligence perspective in supporting decision-making through the collected questionnaires, Table 1 shows the frequencies and percentages

- From the viewpoint of users of business intelligence systems, specialists, and decision makers, they interact with data warehouse, databases, and BI Dashboards, a work environment (user interface), reports and data mining tools in their work regularly by more than $85 \%$, and they also use text mining tools, though to a lesser extent than other tools by an estimated $69 \%$. They rely on business intelligence systems to collect and store data and aanalyze data by more than $85 \%$, and put forward their opinions that help decision-making about current situations and guide future planning by more than $62 \%$, and finally they use business intelligence systems to alert potential problem solutions by more than 55\%, use business intelligence systems Daily by more than $70 \%$, which confirms the high level of penetration of business intelligence solutions in the Saudi Electricity Company at all operational, tactical and strategic levels.

- On the other hand, when examining the role of knowledge management in supporting decisionmaking through the collected questionnaires, the responses of the sample members appeared as indicated in Table (2). 
International Journal of Engineering Research and Technology. ISSN 0974-3154 Vol.13, No.4 (2020), pp. 744-755

(C) International Research Publication House. https://dx.doi.org/10.37624/IJERT/13.4.2020.744-755

Table 2. Responses of the sample members about the role of knowledge management in supporting decision-making

\begin{tabular}{|c|c|c|c|c|c|c|c|}
\hline \multirow[b]{2}{*}{ Questions } & \multirow[b]{2}{*}{ Answers } & \multicolumn{2}{|c|}{ Users } & \multicolumn{2}{|c|}{ Specialists } & \multicolumn{2}{|c|}{ Decision makers } \\
\hline & & responses & Percentage & responses & Percentage & responses & Percentage \\
\hline \multirow{4}{*}{$\begin{array}{l}\text { How do you share knowledge } \\
\text { about inaccurate or } \\
\text { incomplete data in BI } \\
\text { systems? Choose all that } \\
\text { applies (multiple answers } \\
\text { allowed) }\end{array}$} & I inform my boss & 208 & $93 \%$ & 13 & $100 \%$ & 90 & $96 \%$ \\
\hline & \begin{tabular}{|l} 
I inform other \\
colleagues
\end{tabular} & 217 & $97 \%$ & 12 & $93 \%$ & 86 & $92 \%$ \\
\hline & $\begin{array}{l}\text { I share knowledge } \\
\text { with our business } \\
\text { intelligence specialists }\end{array}$ & 177 & $79 \%$ & 0 & $0 \%$ & 94 & $100 \%$ \\
\hline & $\begin{array}{ll}\text { I do not share } \\
\text { knowledge } \\
\text { colleagues }\end{array}$ & 0 & $0 \%$ & 0 & $0 \%$ & 0 & $0 \%$ \\
\hline \multirow{5}{*}{$\begin{array}{l}\text { For what purpose do you share } \\
\text { insights about inaccurate } \\
\text { information from the } \\
\text { perspectives of data accuracy } \\
\text { and completeness? Choose all } \\
\text { that applies } \\
\text { (multiple answers allowed) }\end{array}$} & $\begin{array}{|ll|}\text { To retrieve correct } \\
\text { original data }\end{array}$ & 195 & $87 \%$ & 12 & $93 \%$ & 88 & $94 \%$ \\
\hline & To correct new data & 190 & $85 \%$ & 12 & $93 \%$ & 89 & $95 \%$ \\
\hline & $\begin{array}{l}\text { To identify errors in } \\
\text { business intelligence } \\
\text { system tools that allow } \\
\text { incorrect data }\end{array}$ & 201 & $90 \%$ & 13 & $100 \%$ & 91 & $97 \%$ \\
\hline & $\begin{array}{l}\text { To prevent adding } \\
\text { new incorrect data in } \\
\text { the future }\end{array}$ & 170 & $76 \%$ & 11 & $85 \%$ & 82 & $87 \%$ \\
\hline & $\begin{array}{l}\text { Improving the } \\
\text { company's approach } \\
\text { to dealing with } \\
\text { business intelligence } \\
\text { systems data }\end{array}$ & 180 & $80 \%$ & 11 & $\% 85$ & 85 & $\% 90$ \\
\hline \multirow{6}{*}{$\begin{array}{l}\text { In your opinion, does the } \\
\text { company have effective } \\
\text { processes to prevent incorrect } \\
\text { data from the perspectives of } \\
\text { data accuracy and } \\
\text { completeness in business } \\
\text { intelligence systems? (only } \\
\text { one answer allowed) }\end{array}$} & $\begin{array}{l}\text { The processes used in } \\
\text { the company are } \\
\text { effective }\end{array}$ & 202 & $90 \%$ & 13 & $100 \%$ & 94 & $100 \%$ \\
\hline & $\begin{array}{l}\text { The processes used in } \\
\text { the company are } \\
\text { medium-effective }\end{array}$ & 22 & $10 \%$ & 0 & $0 \%$ & 0 & $0 \%$ \\
\hline & $\begin{array}{l}\text { Processes are rarely } \\
\text { effective }\end{array}$ & 0 & $0 \%$ & 0 & $0 \%$ & 0 & $0 \%$ \\
\hline & $\begin{array}{l}\text { The processes used in } \\
\text { the company are not }\end{array}$ & 0 & $0 \%$ & 0 & $0 \%$ & 0 & $0 \%$ \\
\hline & effective & & & & & & \\
\hline & $\begin{array}{l}\text { I do not know/I cannot } \\
\text { answer }\end{array}$ & 0 & $0 \%$ & 0 & $0 \%$ & 0 & $0 \%$ \\
\hline \multirow{5}{*}{$\begin{array}{l}\text { What is the frequency of } \\
\text { obtaining inaccurate } \\
\text { information in business } \\
\text { intelligence systems? (only } \\
\text { answer allowed) }\end{array}$} & Very high & 0 & $0 \%$ & 0 & $0 \%$ & 0 & $0 \%$ \\
\hline & High & 0 & $0 \%$ & 0 & $0 \%$ & 0 & $0 \%$ \\
\hline & Sometimes & 67 & $30 \%$ & 2 & $15 \%$ & 4 & $4 \%$ \\
\hline & Rarely & 157 & $70 \%$ & 11 & $85 \%$ & 90 & $96 \%$ \\
\hline & Very rarely & 0 & $0 \%$ & 0 & $0 \%$ & 0 & $0 \%$ \\
\hline
\end{tabular}

One of the main elements that affect the process of information integration system is the knowledge management perspective. Table 2 shows the frequencies and percentages for the responses of business intelligence systems users. All employees confirmed that they regularly shared knowledge about inaccurate or incomplete data with their boss and colleagues by $93 \%$ and more, but only $79 \%$ said they reported to the business intelligence specialists. And business 
International Journal of Engineering Research and Technology. ISSN 0974-3154 Vol.13, No.4 (2020), pp. 744-755

(C) International Research Publication House. https://dx.doi.org/10.37624/IJERT/13.4.2020.744-755

intelligence system specialists share with their colleagues $93 \%$ and their boss $100 \%$, while decision makers share knowledge with business intelligence specialists $100 \%$, as well as share with their bosses by $96 \%$ and their colleagues $92 \%$ and throughout the company in general. This indicates that the company generally has an open door policy to exchange knowledge and ideas. Most users state that they share this knowledge about inaccurate information to identify errors in business intelligence tools that allow incorrect data by $90 \%$, to restore correct data and correct new data by more than $85 \%$, improve the company's operations that allowed these errors by $80 \%$, and $76 \%$ share knowledge to prevent adding new incorrect data in the future. More than $97 \%$ of specialists and decision-makers share their ideas about inaccurate information to find errors that have allowed this information in the system, the correct data and recover the correct data above $93 \%$ and prevent inaccurate data from entering the system in the future, and improving business intelligence operations that allowed this error in the company by more than $85 \%$. From these results it is clear that the company generally has an open door policy to exchange knowledge and ideas.

According to the results achieved, most specialists and employees have reported that the company, in general, has effective processes to prevent inaccurate data from entering private business intelligence systems from the viewpoint of users of business intelligence systems at $90 \%$ and specialists and decision makers at $100 \%$. Participants emphasized that the internal business intelligence tools were fairly easy to use, and that all staff received appropriate training and adequate technical support. Finally, the company maintains information security by providing only business intelligence specialists and specific users with special rights to access data management.

This allows ensuring that any data inaccuracies can be traced to the employee responsible for entering or downloading data into the system, or for correcting data in source databases. Most users have stated that obtaining inaccurate information in business intelligence systems, from their point of view, rarely occurs by up to $70 \%$, while specialists report rare occurrence is by up to $85 \%$ and as for decision makers, rare occurrence is by up to $96 \%$, and errors become few unnoticed by the average user in recent years as the company relies on business intelligence systems in addition to good electronic applications..

Below we will answer the questions of this research as follows:

- How does the integration process of business intelligence and knowledge management systems occur to support the information integration system and decision-making processes of the company?

Nearly $74 \%$ of business intelligence systems specialists said that the level of database integration is sufficient, while $26 \%$ of respondents said that they believe that databases need more integration among them, which can be strengthened through a knowledge management perspective. And according to Table 3,
Table 3. responses of the sample members about databases environment

\begin{tabular}{|l|l|l|l|l|}
\hline Question & Answers & Responses & Percentage \\
\hline \begin{tabular}{l} 
Fourth question (is \\
the databases \\
environment (data \\
\cline { 2 - 4 } $\begin{array}{l}\text { warehouses) in the } \\
\text { company } \\
\text { integrated? }\end{array}$
\end{tabular} & Yes & 10 & $77 \%$ \\
\hline
\end{tabular}

the employees confirmed that the company policy is currently working on a project to merge all its databases in a unified data warehouse due to the different types and copies of databases used in the company through the application of ENTERPRISE DATA WAREHOUSE. When a business intelligence or decision-maker user detects data results in the enterprise's business intelligence reports and tools, which do not match expected results and outputs, not because of technical errors in the tools themselves, but because of data discrepancies or data inconsistencies in source databases and platforms, specialists can quickly detect and correct source data violations, as well as on-demand business intelligence reports and tools, scan queries with SQL statements, update SAPrelated source databases and manage the process of enriching this data, add to that, business intelligence users have the responsibility to upload and review business intelligence data and to verify the accuracy and completeness of the data.

Whenever business intelligence systems specialists encounter problems or inaccuracies in business intelligence tools or source databases, they frequently share knowledge and results of inaccurate information with other colleagues, while decision makers are keen to track the cause of inaccurate information to improve the level of information integration system in all the reports presented to them to improve the performance of the company's operations and make better decisions accordingly. Specialists share new information and insights from business intelligence systems with their boss and fellow specialists, and share with other colleagues.

On the other hand, users confirm that they share these visions either in meetings with colleagues or via email, while specialists and decision-makers share them in meetings with colleagues and email, which indicates a potential lack in appropriate documentation of company data correction results. While users confirm that other colleagues also share their results and knowledge about business intelligence systems through meetings and e-mail, indicating that there is no official documentation of these results in the company.

\section{- How is the information integration process performed in the company to ensure data accessibility, accuracy, completeness and security?}

The company has established a set of key performance indicators, procedures and rules aimed at ensuring data accessibility, accuracy, completeness and security. The company's performance is monitored through key performance indicators such as accuracy of information and correct data (accuracy, completeness), rate of use of information, indicators 
of subscribers and users of information technology (accessibility), and system safety index (security).

Analysis of the decision makers' responses, in the questionnaire of investigating the role of business intelligence systems in improving the information integration system resulting from the integration of business intelligence and knowledge management systems to support decisionmaking in the Saudi Electricity Company, refers to the items of data accessibility, data accuracy, data completeness and data security as shown in tables $4-7$

Table 4. decision makers' responses about data accessibility

\begin{tabular}{|c|c|c|c|c|c|}
\hline $\mathrm{S}$ & Data accessibility & $\begin{array}{l}\text { Arithmetic } \\
\text { mean }\end{array}$ & $\begin{array}{l}\text { Standard } \\
\text { deviation }\end{array}$ & $\begin{array}{c}\text { Degree of } \\
\text { agreement }\end{array}$ & Order \\
\hline 1 & $\begin{array}{l}\text { Business intelligence systems have evolved greatly in my } \\
\text { organization over the past years }\end{array}$ & 4.32 & 0.87 & Very high & 7 \\
\hline 2 & Surrounded by more information nowadays than before & 4.35 & 1.02 & Very high & 5 \\
\hline 3 & I get a better insight of data than before & 4.22 & 0.91 & Very high & 10 \\
\hline 4 & $\begin{array}{l}\text { I am aware of new business intelligence systems development } \\
\text { processes in my organization }\end{array}$ & 4.14 & 0.89 & High & 12 \\
\hline \multirow[t]{2}{*}{5} & $\begin{array}{l}\text { The opinion of decision makers is taken into consideration within } \\
\text { the }\end{array}$ & 4.43 & 0.94 & Very high & 3 \\
\hline & organization about business intelligence development processes & & & & \\
\hline 6 & $\begin{array}{l}\text { It is important to have easy access to business intelligence } \\
\text { information }\end{array}$ & 4.58 & 0.79 & Very high & 1 \\
\hline 7 & $\begin{array}{l}\text { It is easy to access everything related to business intelligence } \\
\text { systems within the organization, including information, reports, } \\
\text { tools, etc. }\end{array}$ & 4.08 & 0.96 & High & 13 \\
\hline 8 & $\begin{array}{l}\text { It is important that business intelligence and related systems are } \\
\text { userfriendly }\end{array}$ & 4.48 & 1.04 & Very high & 2 \\
\hline 9 & $\begin{array}{l}\text { Business Intelligence Systems should have a user friendly user } \\
\text { interface }\end{array}$ & 4.28 & 0.93 & Very high & 9 \\
\hline 10 & $\begin{array}{l}\text { I find it easy to use Business Intelligence systems to extract reports } \\
\text { in my work. }\end{array}$ & 4.34 & 1.14 & Very high & 6 \\
\hline 11 & $\begin{array}{l}\text { It is important that business intelligence systems information is } \\
\text { used to make decisions in the company }\end{array}$ & 4.30 & 1.03 & Very high & 8 \\
\hline 12 & $\begin{array}{l}\text { Decision-making depends heavily on the availability of business } \\
\text { intelligence systems information }\end{array}$ & 4.22 & 0.93 & Very high & 11 \\
\hline 13 & $\begin{array}{l}\text { I often make decisions based on available business intelligence } \\
\text { systems }\end{array}$ & 4.40 & 0.90 & Very high & 4 \\
\hline & Total & 4.27 & 0.71 & Very hi & gh \\
\hline
\end{tabular}

It is clear from the above results that data accessibility in general, according to the responses of decision makers has a very large degree, with an arithmetic mean of 4.27 , and the responses of the sample members on most of the items of this axis, by about 11 items to a very large extent, with arithmetic means ranging from (4.22 to 4.58), And two items with a high degree of agreement and arithmetic means $(4.14 ; 4.08)$, as standard deviations showed minimal dispersion values for these responses, as those values ranged between ( 0.79 to 1.04 ). 
International Journal of Engineering Research and Technology. ISSN 0974-3154 Vol.13, No.4 (2020), pp. 744-755

(C) International Research Publication House. https://dx.doi.org/10.37624/IJERT/13.4.2020.744-755

Table 5. decision makers' responses about data accuracy

\begin{tabular}{|c|c|c|c|c|c|}
\hline $\mathrm{S}$ & Data accuracy & $\begin{array}{l}\text { Arithmetic } \\
\text { mean }\end{array}$ & $\begin{array}{l}\text { Standard } \\
\text { deviation }\end{array}$ & $\begin{array}{l}\text { Degree of } \\
\text { agreement }\end{array}$ & Order \\
\hline 1 & $\begin{array}{l}\text { The information in Business Intelligence Systems tools should always } \\
\text { be correct }\end{array}$ & 4.34 & 1.04 & Very high & 4 \\
\hline 2 & $\begin{array}{l}\text { Organizations need processes to ensure the accuracy of data in } \\
\text { business intelligence systems }\end{array}$ & 4.56 & 1.03 & Very high & 1 \\
\hline 3 & $\begin{array}{l}\text { Decision-making employees are responsible for maintaining the } \\
\text { validity of the data }\end{array}$ & 4.31 & 1.08 & Very high & 6 \\
\hline 4 & $\begin{array}{l}\text { Organizations should have business intelligence systems specialists } \\
\text { responsible for maintaining the validity of the data }\end{array}$ & 4.42 & 0.90 & Very high & 2 \\
\hline 5 & $\begin{array}{l}\text { My daily work is heavily influenced by the quality and accuracy of } \\
\text { data in business intelligence systems }\end{array}$ & 4.36 & 0.90 & Very high & 3 \\
\hline 6 & $\begin{array}{l}\text { The company is heavily influenced by the quality and accuracy of data } \\
\text { in business intelligence systems }\end{array}$ & 4.32 & 0.83 & Very high & 5 \\
\hline 7 & $\begin{array}{l}\text { The business intelligence system provides me with enough } \\
\text { information to make important decisions }\end{array}$ & 4.25 & 0.86 & Very high & 8 \\
\hline 8 & $\begin{array}{l}\text { Decision making depends heavily on the accuracy of information } \\
\text { related to business intelligence systems }\end{array}$ & 4.28 & 0.94 & Very high & 7 \\
\hline 9 & Accuracy of business intelligence information is important to me & 4.14 & 1.01 & High & 9 \\
\hline & Total & 4.33 & 0.71 & \multicolumn{2}{|c|}{ Very high } \\
\hline
\end{tabular}

The above results show the agreement among decision makers on verifying data accuracy in business intelligence systems with a very high degree, with an arithmetic mean of 4.33 ; and the responses of the sample members to 8 of the total 9 items within this axis, had a very high degree, with arithmetic means ranging from ( 4.25 to 4.56 ), and one item with a high degree of agreement with an arithmetic mean (4.14). Standard deviations also showed minimal dispersion values for these responses, as those values ranged between ( 0.77 to 1.08$)$.

Table 6. decision makers' responses about data completeness

\begin{tabular}{|c|l|c|c|c|c|}
\hline $\mathrm{S}$ & Data completeness & $\begin{array}{c}\text { Arithmetic } \\
\text { mean }\end{array}$ & $\begin{array}{c}\text { Standard } \\
\text { deviation }\end{array}$ & $\begin{array}{c}\text { Degree of } \\
\text { agreement }\end{array}$ & Order \\
\hline 1 & $\begin{array}{l}\text { The information in the business intelligence system tools should } \\
\text { always be complete }\end{array}$ & 4.69 & 0.62 & Very high & 1 \\
\hline 2 & $\begin{array}{l}\text { Organizations need processes to ensure that business intelligence } \\
\text { information is new and complete }\end{array}$ & 4.58 & 0.67 & Very high & 5 \\
\hline 3 & $\begin{array}{l}\text { Decision-making employees are responsible for maintaining the } \\
\text { update and completeness of data }\end{array}$ & 4.63 & 0.62 & Very high & 4 \\
\hline 4 & $\begin{array}{l}\text { My daily work depends heavily on the level of information } \\
\text { completeness }\end{array}$ & 4.47 & 0.66 & Very high & 7 \\
\hline 5 & $\begin{array}{l}\text { The company relies heavily on the level of information } \\
\text { completeness }\end{array}$ & 4.63 & 0.52 & Very high & 3 \\
\hline 6 & $\begin{array}{l}\text { I frequently update business intelligence systems tools with new } \\
\text { data to ensure that information completeness }\end{array}$ & 4.35 & 0.81 & Very high & 8 \\
\hline 7 & $\begin{array}{l}\text { Decision-making is highly dependent on whether or not business } \\
\text { intelligence systems information is complete }\end{array}$ & 4.54 & 0.62 & Very high & 6 \\
\hline 8 & $\begin{array}{l}\text { Completeness of business intelligence systems information is } \\
\text { important to my business }\end{array}$ & 4.64 & 0.63 & Very high & 2 \\
\hline \multicolumn{1}{|c|}{ Total } & 4.57 & $\mathbf{0 . 4 2}$ & \multicolumn{2}{|c|}{ Very high } \\
\hline
\end{tabular}


The above results shows that the agreement among decision makers that data completeness is achieved in business intelligence systems with a very high degree with an arithmetic mean of 4.57; and the responses of the sample members to 7 of the 8 items within this axis, had a very high degree, with arithmetic means ranging from (4.35) To (4.69), and one item with a high degree of agreement with an arithmetic mean (4.14), as standard deviations showed minimal dispersion values for these responses, as those values ranged between (0.62 to 0.81$)$.

Table 7. decision makers' responses about data security

\begin{tabular}{|c|c|c|c|c|c|}
\hline $\mathrm{S}$ & Data security & $\begin{array}{c}\text { Arithmetic } \\
\text { mean }\end{array}$ & $\begin{array}{l}\text { Standard } \\
\text { deviation }\end{array}$ & $\begin{array}{l}\text { Degree of } \\
\text { agreement }\end{array}$ & Order \\
\hline 1 & $\begin{array}{l}\text { It is important that business intelligence information is protected and } \\
\text { secure }\end{array}$ & 4.32 & 0.73 & Very high & 6 \\
\hline 2 & $\begin{array}{l}\text { Organizations need processes to ensure the security of business } \\
\text { intelligence information }\end{array}$ & 4.40 & 0.69 & Very high & 1 \\
\hline 3 & $\begin{array}{l}\text { To ensure information protection and security, organizations should have } \\
\text { distinct user roles with a different rights to access data to ensure its } \\
\text { integrity }\end{array}$ & 4.31 & 0.73 & Very high & 7 \\
\hline 4 & $\begin{array}{l}\text { The safety and security of business intelligence information is important } \\
\text { to me }\end{array}$ & 4.34 & 0.78 & Very high & 5 \\
\hline 5 & $\begin{array}{l}\text { My daily work relies heavily on the security of business intelligence } \\
\text { systems }\end{array}$ & 4.39 & 0.75 & Very high & 2 \\
\hline 6 & The company relies heavily on business intelligence information security & 4.35 & 0.75 & Very high & 4 \\
\hline 7 & $\begin{array}{l}\text { Decision-making depends heavily on whether business intelligence } \\
\text { systems information is secure }\end{array}$ & 4.25 & 0.73 & Very high & 8 \\
\hline 8 & $\begin{array}{l}\text { Business intelligence systems security is essential for information } \\
\text { security }\end{array}$ & 4.36 & 0.67 & Very high & 3 \\
\hline & Total & 4.34 & 0.40 & \multicolumn{2}{|l|}{ Very hi } \\
\hline
\end{tabular}

The above results show the agreement among decision makers, with a very high degree and an arithmetic mean of 4.34 , that data security is achieved in business intelligence systems; and the responses of the sample for all items of this axis, had a very high degree, with arithmetic means ranging between (4.25 to 4.40), the standard deviations also showed minimal dispersion values for these responses, as those values ranged between (0.67 to 0.78$)$.

The results of the analysis of the responses of the study sample respondents show that business intelligence systems users and specialists, and decision-makers agree with a very large degree on the role of business intelligence systems in achieving data accessibility, completeness, accuracy and security in general, and they all strongly agree about all items. This is evidence that they share the same views regarding the critical importance of the four elements of its business, and that the company provides a stable ecosystem where ideas and knowledge about data gaps or inaccuracies are shared by users to ensure the accuracy and completeness of the data

- What are the motives and reasons for improving the information integration process in the company?

The results of analyzing the responses of the study sample indicated that the high quality of business intelligence systems information contributes to improving the quality of their work, and thus to improving operational efficiency. Participants noted that the primary advantage of business intelligence systems enhanced with human knowledge is in direct saving of resources, reducing costs, reducing the time needed to perform operational activities, and contributing to managing overall business performance and organizational efficiency. Almost all decision makers have stated that business intelligence systems, when enhanced with human knowledge and expertise, become essential in contributing to decision-making for the better and have a significant impact on the long-term planning of an organization.

\section{- How does the information integration system process contribute to supporting source data in the company's data warehouse?}

According to the participants, the process of consolidating and enriching company databases usually begins when a user or specialist discovers inaccurate or incomplete information, or when new knowledge is obtained through the use of business intelligence tools that must be added to the source data used by the company. Table (8) shows the responses of the sample 
members about detecting incorrect information from the perspective of data accuracy in business intelligence systems .

Table 8. responses of the sample members about detecting incorrect information from the perspective of data accuracy in business intelligence systems

\begin{tabular}{|c|c|c|c|}
\hline Question & Answers & Responses & Percentage \\
\hline \multirow{3}{*}{$\begin{array}{l}\text { If incorrect } \\
\text { information } \\
\text { exists from a data } \\
\text { accuracy } \\
\text { perspective in } \\
\text { business } \\
\text { intelligence } \\
\text { systems, how is } \\
\text { this discovered? } \\
\text { Choose all that } \\
\text { apply. }\end{array}$} & $\begin{array}{l}\text { Alerts from } \\
\text { business } \\
\text { intelligence } \\
\text { systems }\end{array}$ & 7 & $54 \%$ \\
\hline & $\begin{array}{l}\text { SQL/search } \\
\text { queries }\end{array}$ & 3 & $23 \%$ \\
\hline & $\begin{array}{l}\text { Signals from } \\
\text { business } \\
\text { intelligence } \\
\text { users }\end{array}$ & 3 & $23 \%$ \\
\hline
\end{tabular}

By reference to Table No. 8, regarding incorrect information in business intelligence systems, it is usually determined by system operators at $54 \%$, search or SQL queries by $23 \%$ or by references from business intelligence users by $23 \%$. Information about inaccurate or incomplete information is provided to other users and specialists of the company through periodic reports, internal meetings, or other forms of communication, such as communication written in email and company chat.
Once the problem is discovered or the information needs to be updated, the user or the relevant business intelligence specialist responsible for ensuring the accuracy or updating of the data will take responsibility for the process concerned. Business intelligence users have stated that they often search for the cause of errors and correct the data themselves, or seek support from other colleagues and business intelligence specialists. Once the issue is resolved, users usually share their results with other colleagues, management, and business intelligence specialists through internal communication tools, such as meetings, email, internal chats, and reports. Automated knowledge exchange occurs mainly through the use of SQL checking queries, which send an automated report of detected data errors to specific users who have roles in fixing such errors. Such reports are exchanged through a pre-programmed email sending function, a popup window, or automated notification within the ERP system. Automated reports include a list of responsible roles within the organization, who should be informed of data inconsistencies and may be tasked with solving basic problems in the source database, SQL queries, or technical system functions; these roles are usually assigned to users of business intelligence systems with high technical skill, although these roles can also be assigned to business intelligence system specialists or other positions in the company. Based on the above, the data consolidation process can be presented in the Saudi Electricity Company as shown in Figure No. (2) as follows:

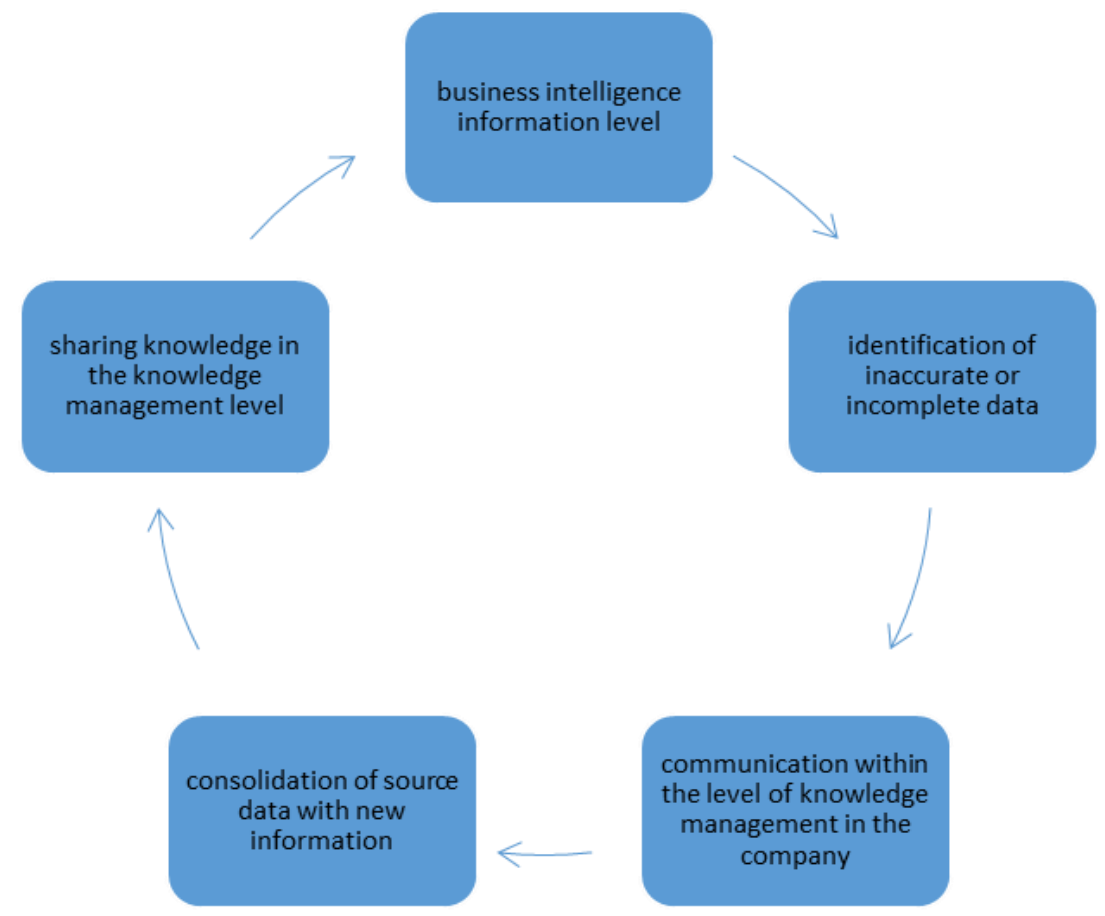

Fig.2. data consolidation process in the Saudi Electricity Company

Consequently, it can be concluded that the company's source data consolidation process follows the framework of the information integration process proposed by Niesel [6], by seeking to ensure the accuracy and completeness of main data in business intelligence systems. 
- What are the challenges facing the company in the process of information integration system?

Data accuracy is the primary challenge facing business intelligence users, specialists, and decision-makers. From a human knowledge management perspective, the company faces challenges in documenting its knowledge. Although there is a knowledge hub, knowledge such as modern project designs and technical systems development projects is stored through Knowledge Network System and shared in the future, or used for the purpose of applying a text mining tool to extract additional ideas, while the mechanism of detecting and correcting the knowledge resulting from error correction is not documented, thus, it becomes clear that the majority of knowledge is not documented. 55\% of business intelligence users have answered that they are taking advantage of business intelligence systems to receive early warning signs of potential business and technical problems appeared as indicated in Table (1). In contrast, more than $77 \%$ of specialists assert that business intelligence tools have been used to issue early warning signs of potential problems, and company decision makers have also confirmed that they rely on business intelligence systems to obtain early warning signs of $94 \%$. This may indicate a lack of communication between business intelligence specialists and users while indicating how business intelligence information is used in the company; if early warning signs about potential problems are already emitted from business intelligence systems but not communicated effectively to business intelligence users, this means that there is deficiency in information flow and knowledge transfer, which must be addressed in the organization. This may indicate that the company does not use business intelligence tools to the fullest in order to efficiently manage risk and prevent undesirable crises or technical problems. Therefore, it appears that information and reports from business intelligence systems are used to provide a larger business context associated with current and future decisions, but are not used as predictive tools to anticipate and prevent potential serious problems at the operational level.

\section{- How is the resulting integrated information system used to support the company's decision-making?}

Here, participants emphasized that business intelligence tools are used in financial operations, sales and customer relations, and less clearly in logistics and human resource management processes - although a human resource management model is available in the company's SAP system, it appears to be the area in which business intelligence tools are least infiltrated in the company. This may partially confirm the prior finding that business intelligence information is not strengthened and used to support predictive analytical processes that may help identify potential logistical and human resource shortcomings in the company. This factor may lead to a potential obstacle in the competitive landscape, because the company may not be able to manage its employees and team performance effectively due to incomplete or inaccurate data, which is dependent only on tacit human knowledge, but it has not gone through the process of integrating information between business intelligence and knowledge management. participants consider that the information currently available in the company's business intelligence system is very useful in decision-making and that they often make decisions based on business intelligence information resulting from the information integration process, and that the company must invest in the continuous development of human resources and keep abreast of continuous updates in modern information technologies. This confirms the value attributed by decision makers to the role intellectual capital plays in collecting business intelligence data, verifying its validity and enhancing it to support improving the information integration system for optimal decision making.

\section{CONCLUSION AND RECOMMENDATION}

The Saudi Electricity Company organizes an organizational structure that provides the necessary support to business intelligence users, specialists and decision makers in understanding the data available in business intelligence systems, certifying their authenticity, acquiring new ideas and making more confident decisions that affect the overall organizational strategy. The company's information system structure provides robust practices to ensure information accessibility, accuracy, completeness and security in business intelligence systems. Business intelligence users, specialists, and decision makers who use business intelligence tools also assure that the tools provide them with increasing levels of information and ideas that enable optimal decision-making in a faster, more reliable and more efficient manner. Moreover, enhancing business intelligence information by human knowledge through the means of knowledge exchange, information transfer and presenting ideas through verbal and written communication is crucial to their work because it provides verification of information accuracy and provides them with additional knowledge which proves its extreme importance in cases of high market competitiveness. This indicates that data consolidation is firmly rooted in the company's knowledge sharing and information transfer practices. While the lack of adequate documentation of the company's operations leads to repetition of previous mistakes or ineffective behavior patterns, prevents the organization from learning from previous operational situations in a complete manner, and slows down overall organizational learning.

The researchers recommends taking the following points into consideration:

1. Organizations seeking operational efficiency should establish institutional policies, rules and practices that encourage knowledge integration document the lessons learned from the process of improving the integrity of the information system in the internal knowledge repository, and make this information available for use by all relevant stakeholders, to ensure that important implicit knowledge On the process of transferring information and integrating business intelligence and knowledge management it will not be lost and can be reused in the future to support faster, more accurate and more reliable information integration processes.

2. Organizations to establish regular open meetings and 
presentations with the aim of discussing best practices in using business intelligence systems and sharing key challenges or important feedback regarding business intelligence tools. As with other knowledge sharing practices, it is important for organizations to establish formal practices for proper documentation of such meetings in order to ensure that the resulting knowledge is transformed from explicit, reliable and clear knowledge that can be uploaded to the organization's knowledge hub.

3. Verification of source data must be applied in the organization's databases, and completed and supported from a knowledge management perspective, and there is still a lack in its application mechanism, and to ensure that it is applied effectively to organizations, internal research must be conducted to benefit from the experiences of intellectual capital in addressing problems during application.

4. Future research should address the process of integrating knowledge resulting from the integration of business intelligence and knowledge management and the role that machine learning and artificial intelligence solutions can play to support more effective integration of information and better decision-making in organizations.

5. The need to conduct future research to study knowledge management systems and integrate them with business intelligence systems in order for organizations to achieve strategic intelligence and its role in enhancing strategic performance and better decision makers.

\section{REFERENCES}

[1] Dawdi, E; Mousa, Abdul N (2012). Knowledge management and business intelligence: integration or difference?, a paper presented to "the 11th annual scientific conference on business intelligence and knowledge economy (April 23rd-26th, 2012)", Faculty of Economics, Al-Zaytoonah University of Jordan, Amman, Jordan.

[2] Alrumaih, H., \& Zemirli, N. (2014). Investigation of knowledge management support for business intelligence in the Saudi Public Sector. Volume One, 39.

[3] Rostami, N. A. (2014). Integration of Business Intelligence and Knowledge Management - A literature review. Journal of Intelligence Studies in Business 4(2): 30-40.

[4] Cheng, L., \& Cheng, P. (2011). Integration: Knowledge Management and Business Intelligence. Conference paper presented at the 2011 Fourth International Conference on Business Intelligence and Financial Engineering.

[5] Sharda, R., Delen, D., \& Turban, E. (Eds.) (2014). Business Intelligence: A Managerial Perspective on Analytics: Pearson.

[6] Niesel, C. (2018). Information integrity: A proposal to improve the integration of knowledge management and business intelligence for better decision-making.
Graduation Assignment, Open University of the Netherlands.

[7] Kasemsap. K., ( 2015 )."The Role of Data Mining for Business Intelligence in Knowledge Management", Integration of Data Mining in Business Intelligence Systems, pp. 12-33,

[8] Shehzad, R., \& Khan, M. N. A. (2013). Integrating Knowledge Management with Business Intelligence Processes for Enhanced Organizational Learning. International Journal of Software Engineering and Its Applications, (7:2): 83-93.

[9] Chang, K., Kettinger, W.J., \& Zhang, C. (2009). Assimilation of Enterprise Systems: The Mediating Role of Information Integration of Information Impact. ICIS 2009 Proceedings. Paper 90: $1-12$. 